\section{Arthropod diversity in pure oak forests of coppice origin in northern Thrace (Turkey)}

\author{
Akif Keten $^{(1)}$, Vedat Beskardes ${ }^{(2)}$, Meric Kumbasli ${ }^{(1)}$, Ender Makineci ${ }^{(3)}$, \\ Hayati Zengin ${ }^{(4)}$, Emrah Özdemir ${ }^{(5)}$, Ersel Yilmaz ${ }^{(5)}$, Hatice Cinar \\ Yilmaz ${ }^{(6)}$, Servet Caliskan ${ }^{(7)}$, James T Anderson ${ }^{(8)}$
}

Oak (Quercus spp.) forests are among the most important forest types in Turkey. In the past, oak forests were managed through coppice clear-cutting, but in recent decades they have mostly been converted to high forest. This study was aimed at explaining how arthropod diversity is affected during conversion from coppice to high oak forest and during the early stages of coppice succession. We tested the hypothesis that arthropod richness, abundance and diversity in coppice oak sites varied according to stand age and a number of other forest characteristics. Arthropod communities were sampled in 50 plots using four different methods: pitfall traps, sweep nets, sticky cards and cloth shaking. A total of 13084 individuals were collected and classified into 193 Recognizable Taxonomic Units (RTUs), with the most RTUs and the greatest number of specimens captured by sweep netting. We identified 17 taxa within RTU's with more than $1 \%$ of the captured arthropods, which constituted $75 \%$ of the total specimens. The number of RTUs varied significantly according to trap type. Arthropod richness and Shannon-Wiener biodiversity index $\left(H^{\prime}\right)$ increased with elevation and precipitation. In young (1-40 yrs-old) and middle-aged (4180 yrs) stands, arthropod biodiversity was not significantly affected by stand type, but slightly increased with diameter at breast height and tree height. Forest characteristics, such as the litter layer, understory and crown diameter, weakly influenced arthropod richness and abundance. Cluster analysis revealed that stand types and trap types differed taxonomically. Principal component analysis showed that stand types were clearly separated by the stand parameters measured. Insect families (Formicidae, Thripidae, Lygaeidae, Dolichopodidae, Luaxanidae, Cicadellidae and Ichneumonidae) could potentially be used as indicators of coppice oak conditions. As the coppice oak changes to mature forest, further studies are needed to better assess the relation between arthropods, forest types and structural characteristics of stands.

Keywords: Elevation, Quercus, Recognizable Taxonomic Units, Trap Types, Stand Types, Stand Characteristics

\section{Introduction}

Turkey is one of the world's richest countries in terms of the variety of oak species and their extent. Oak forests cover vast areas in Northern Thrace (European Part of Turkey): 656004 ha, or $27.7 \%$ of the entire land area, of which oak forests make up $71.7 \%$ of forest lands (Makineci et al. 2011). In the past, most oak forests were managed as coppice via clear cuttings on 20 -year rotations. However, the intensive use of the forest led to its long-term degradation. Therefore, Turkish General Directorate of Forestry abandoned such practice in the last decade, and now promotes conversion to high forest and natural regeneration from seeds.

Arthropods are often used as ecological indicators of ecosystem integrity (King et al. 1998, Tscharntke et al. 1998, Rainio \& Niemelä 2003, Langor \& Spence 2006, Maleque et al. 2009). They play essential roles in ecosystems such as pollination, seed disper- sal, nutrient cycling, and they serve as predators of pests and prey for valued vertebrates (Engelmann 1961, van Straalen 1998). Arthropods also have short generation times and respond quickly to ecological changes (Work et al. 2002). Habitat structure influences arthropod diversity and abundance (Spitzer et al. 2008). In general, systems that are more diverse, permanent, isolated and managed with low intensity are associated with high arthropod community diversity (Akbulut et al. 2003). Increasing plant diversity has been suggested as a means of increasing insect diversity (Symstad et al. 2000) and thus lowering insect herbivore damage through decreased host plant density, increased interspecific competition among pest and non-pest species and improved natural enemy communities (Stamps \& Linit 1998).

Arthropod species richness generally increases with stand age (Siemann et al. 1999, $\square$ (1) Duzce University, Faculty of Forestry, Wildlife Ecology and Management, Duzce (Turkey); (2) Istanbul University, Faculty of Forestry, Forest Entomology and Protection Department, Istanbul (Turkey); (3) Istanbul University, Faculty of Forestry, Soil Science and Ecology Department, Istanbul (Turkey); (4) Duzce University, Faculty of Forestry, Department of Forest Management, Duzce (Turkey); (5) Istanbul University, Faculty of Forestry, Forest Yield and Biometry Department, Istanbul (Turkey); (6) Istanbul University, Forestry Vocational High School, Ornamental Plants Growing Program, Istanbul (Turkey); (7) Istanbul University, Faculty of Forestry, Silviculture Department, Istanbul (Turkey); (8) West Virginia University, Division of Forestry and Natural Resources, Morgantown, West Virginia (USA)

\section{@ Akif Keten (akifketen@yahoo.com)}

Received: Apr 20, 2014 - Accepted: Aug 19, 2014

Citation: Keten A, Beskardes V, Kumbasli M, Makineci E, Zengin H, Özdemir E, Yilmaz E, Yilmaz HC, Caliskan S, Anderson JT, 2014. Arthropod diversity in pure oak forests of coppice origin in northern Thrace (Turkey). iForest 8: 615-623 [online 2014-12-17] URL: http://www.sisef.it/iforest/contents/? id=ifor1318-007

Communicated by: Massimo Faccoli

Bolger et al. 2000), and richness and density of herbivorous insects are influenced by forest age (Jeffries et al. 2006). However, there is limited knowledge about arthropod diversity during the conversion of coppices to high oak forests and the early stages of succession of coppice oak forests in Turkey. In the present study, we hypothesized that arthropod richness, abundance and diversity at coppice oak sites increased with stand age. The objectives of our study were to: (1) identify differences in forest characteristics among forest stand types; (2) characterize differences in arthropod richness, diversity, and abundance among forest stand types, and (3) relate invertebrate taxa to method of capture and to forest stand characteristics.

\section{Materials and methods}

\section{Study sites}

This study was carried out in pure oak stands growing at five different sites $(\mathrm{Ca}-$ talca, Demirkoy, Igneada, Kirklareli and Vize) in the Northern Thrace, Turkey (Fig. 1). Sites were coppice-originated forests, but currently are being converted to high forest. Climate (precipitation, temperature and wa- 


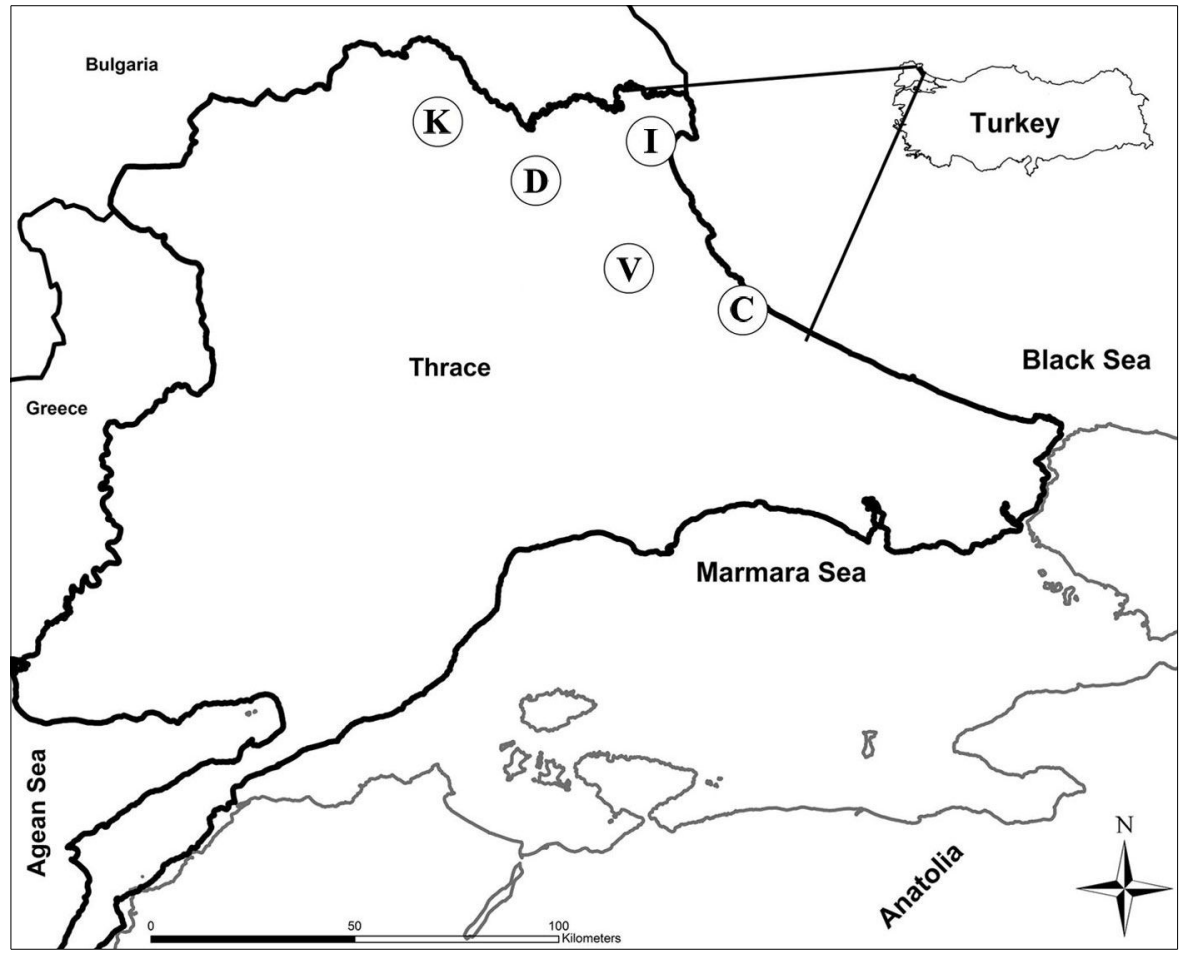

Fig. 1 - Map of Northern Thrace (Turkey) with the location of sampling sites (circles). (C): Catalca; (D): Demirkoy; (I): Igneada; (K): Kirklareli; (V): Vize.

ter deficit) and elevation varied among areas (Tab. 1). Common oak species are Sessile oak (Quercus petraea (Mattuschka) Liebl.), Hungarian oak ( $Q$. frainetto Ten.) and Turkey oak (Q. cerris L. - Makineci et al. 2011) The previous history of rotations and the clear-cut schedules were unfortunately unknown for coppices at the study sites.

Stand formations at each study plot were identified through forest management plans and field studies. Stands were classified by mean diameter at breast height $(\mathrm{DBH})$ as: "a" 0-8 cm; "b" 9-20 cm; and "c" 21-36 cm; or as degraded stands ("Dg") with a canopy closure of less than $10 \%$, following categories used by the Ministry of Forestry and Water Affairs of the Republic of Turkey. Stand ages were determined according to Leatherberry et al. (2006).

Data collection and arthropods sampling

For faunal studies, we selected a total of 50 plots distributed across different elevations

Tab. 1 - Main characteristics of the oak sampling sites (source: Makineci et al. 2011).

\begin{tabular}{lccccr}
\hline $\begin{array}{l}\text { Sampling } \\
\text { Site }\end{array}$ & $\begin{array}{c}\text { Mean } \\
\text { Elevation (m) }\end{array}$ & $\begin{array}{c}\text { Min-max } \\
\text { slope (\%) }\end{array}$ & $\begin{array}{c}\text { Mean annual } \\
\text { precipitation } \\
(\mathbf{m m})\end{array}$ & $\begin{array}{c}\text { Average } \\
\text { annual } \\
\text { temp. }\left({ }^{\circ} \mathbf{C}\right)\end{array}$ & $\begin{array}{c}\text { Annual water } \\
\text { deficit (mm) }\end{array}$ \\
\hline Catalca (C) & 290 & $0-20$ & 844 & 14 & 212 \\
Demirkoy (D) & 680 & $10-60$ & 1053 & 11 & 84 \\
Igneada (I) & 125 & $0-90$ & 867 & 13 & 181 \\
Kirklareli (K) & 500 & $0-50$ & 550 & 14 & 274 \\
Vize (V) & 320 & $0-45$ & 720 & 12 & 244 \\
\hline
\end{tabular}

all herbaceous mass in a $1 \mathrm{~m}^{2}$ area, while samples of the litter were taken from a 0.25 $\mathrm{m}^{2}(50 \times 50 \mathrm{~cm})$ area by collecting all litter over mineral soil. In the laboratory, understory and litter samples were dried at $70{ }^{\circ} \mathrm{C}$ for $>24 \mathrm{~h}$ to a constant mass and weighed (Makineci et al. 2011).

Arthropods were sampled in July 2009 at each of the 50 plots using four different trapping methods: pitfall traps (Work et al. 2002), sweep netting (Siemann et al. 1998), sticky cards (Hamilton et al. 2012) and cloth shaking (Akbulut et al. 2003). Each $100 \times$ $100 \mathrm{~m}$ plot was divided into 16 subplots $(25$ $\times 25 \mathrm{~m}$ ) and enumerated for allocation of sampling points. For pitfall traps, four holes, $15 \mathrm{~cm}$ in diameter and $15 \mathrm{~cm}$ in depth, were made in the ground. Pitfall traps (plastic cups) were placed and checked $24 \mathrm{~h}$ later for soil-dwelling arthropods. Traps were set at equal distances along the diagonal at subplots numerated as $1,6,11$ and 16 in each sample plots and filled to a depth of $2 \mathrm{~cm}$ with ethylene glycol as a preservative. Three of the 200 cups were damaged by wild boar (Sus scrofa). Twenty sweeps with a sweep net were collected from two randomly chosen subplots; these samples were used to evaluate the diversity and number of arthropods present in ground vegetation. Yellow sticky cards, $15 \times 30 \mathrm{~cm}$, were hung on a randomly selected tree in subplots 7 and 10 , placed at approximately mid-canopy height for canopy arthropods and removed $24 \mathrm{~h}$ later. Cloth-shaking sampling was used to sample arthropods in the oak canopies. A tree in each of two randomly selected subplots was shaken three times over a piece of cloth $(3 \times 3 \mathrm{~m})$, using the branches rather than the stem for trees thicker than $5 \mathrm{~cm}$ DBH. Arthropods falling on the cloth were collected and preserved.

\section{Data analyses}

We determined the number of trees per hectare, average $\mathrm{DBH}$, height and crown diameter in the sampling plots. To test for differences between forest variables, including litter mass $\left(\mathrm{kg} \mathrm{ha}^{-1}\right)$, understory mass $(\mathrm{kg}$ $\mathrm{ha}^{-1}$ ), tree density (no ha-1), percentage of snags at sampling sites (Catalca, Demirkoy, Igneada, Kirklareli, Vize), and stand types ("a", "b", "c" and "Dg"), we used one-way analysis of variance (ANOVA). Collected arthropods were counted and categorized into Recognizable Taxonomic Units (RTUs), based on easily recognized features which can be used for rapid assessment of biodiversity (Oliver \& Beattie 1993). We calculated diversity index (Shannon-Wiener $H^{\prime}$ ) based on RTUs. ANOVA was used to compare the number of RTUs, $H^{\prime}$ and number of specimens on sampling sites to stand types. Because of the high degree of variation in arthropod densities, significance was set at $\alpha$ $=0.10$. Separate regressions were performed 

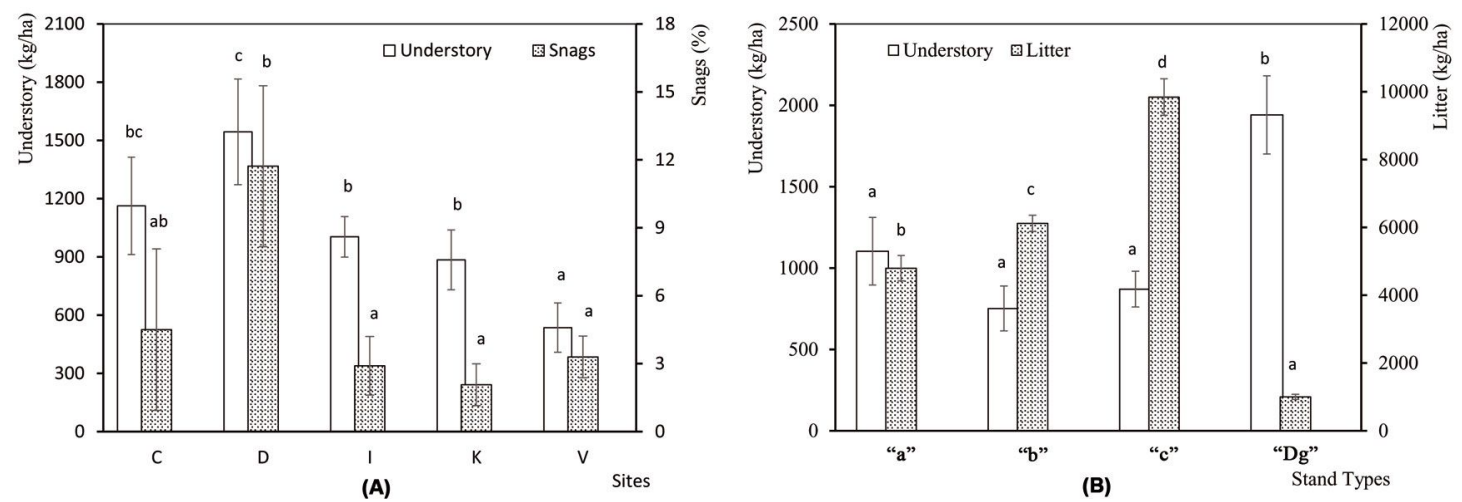

Fig. 2 - (A) Mean understory mass and percentage of snags at the five sampling sites analyzed. (C: Catalca; D: Demirkoy; I: Igneada; K: Kirklareli; V: Vize). (B) Mean understory mass and litter mass in the 4 stand types analyzed. ("a": mean DBH 0-8 cm; "b": 9-20 cm; "c": 21 $36 \mathrm{~cm}$; "Dg": degraded stands with a canopy closure $<10 \%$ ). Error bars represent the standard deviation. Different letters among bars indicate significant differences after ANOVA $(\mathrm{p}<0.05)$.

to examine the relationship between percentage of snags and total arthropods, the litter mass and soil-dwelling arthropods, and between understory mass and arthropods present in the understory. We determined taxa within RTUs that comprised more than $1 \%$ of the total, which in turn constituted $75 \%$ of all specimens. Each group of RTU specimens were compared between stand types and trapping method. We also made use of Akaike's Information Criterion (AIC) to describe the best model determined by the smallest $\mathrm{AIC}_{\mathrm{c}}$ value (Burnham \& Anderson 2002) with $H^{\prime}$ and $\mathrm{DBH}$, height and crown diameter related to stand type. Cluster analysis and analysis of similarity (ANOSIM) was used to categorize sampling plot and trap types by RTU, using Ward's linkage and Bray-Curtis distance metrics. Principal component analysis (PCA) was used to differentiate stand types based on all parameters measured in the study. To determine the degree of importance for each parameter in the ordination model, a Pearson's (r) correlation analysis was conducted between variables. All tests were carried out using the software package RGui version 3.0.2 (R Development Core Team 2013).

\section{Results}

\section{Stand characteristics}

Three oak species (Sessile oak, Hungarian oak and Turkey oak) were present in the sampling plots. Sessile oak was the most common species at all sites except at Ignea$\mathrm{da}$, where Hungarian oak was the most prevalent species. Although Sessile oak was dominant in Demirkoy and Catalca, the other oak species also were prevalent in Vize and Kirklareli. Additional forest tree species were ash (Fraxinus excelsior L., F. ornus L.), Oriental beech (Fagus orientalis Lipsky), maple (Acer campestre L., A. platanoides L.), hornbeam (Carpinus betulus L., $C$. orientalis Mill.). Fruit-bearing shrubs were also recorded, such as rowan (Sorbus aucuparia L., S. domestica L., S. torminalis L.), common hawthorn (Crataegus monogyna Jacg.), wild plum (Prunus avium L., P. divaricate Ledep., P. spinosa L.), dogwood (Cornus mas L.), wild apple (Malus sp.) and medlar (Mespilus germanica L.). The average age of trees in the stand type "a" was 13 \pm 5 years, $63 \pm 8$ in type "b" and $76 \pm 15$ in type "c". Stand type "a" was categorized as "young" (1-40 years old), while "b" and "c" as "middle-aged" (41-80 years old).

The understory mass and the percentage of snags were significanty different among sampling sites $\left(\mathrm{F}_{[4,45]}=3.54, \mathrm{P}=0.014\right.$ and $\mathrm{F}_{[4,45]}=2.83, \mathrm{P}=0.036$, respecively), while no differences were detected in litter mass among sites $\left(\mathrm{F}_{[4,45]}=0.14, \mathrm{P}=0.967\right)$. The understory and snags were most abundant in Demirkoy (Fig. 2a). Differences among stand types were significant for understory $\left(\mathrm{F}_{[3,46]}=4.95, \mathrm{P}=0.005\right)$ and litter $\left(\mathrm{F}_{[3,46]}=\right.$ 52.82, $\mathrm{P}<0.001)$, but not for snags $\left(\mathrm{F}_{[3,46]}=\right.$ $1.01, \mathrm{P}=0.398)$. Litter mass was highest in "c" stands, and the understory mass was greatest in "Dg" stands (Fig. 2b). Number of trees per hectare was significantly different $\left(\mathrm{F}_{[3,46]}=5.135, \mathrm{P}=0.004\right)$ among stand types. The standard deviation was high in young stands, and decreased with age. $\mathrm{DBH}$ $\left(\mathrm{F}_{[3,46]}=198, \mathrm{P}<0.001\right)$, height $\left(\mathrm{F}_{[3,46]}=92.2\right.$, $\mathrm{P}<0.001)$ and crown diameter $\left(\mathrm{F}_{[3,46]}=40.9\right.$, $\mathrm{P}<0.001$ ) increased with age (Fig. 3a, Fig. $3 b)$.

\section{Arthropod data}

In total, arthropod sampling caught 13084 individuals of 193 RTUs from the four combined sampling methods (Tab. 2). The num-
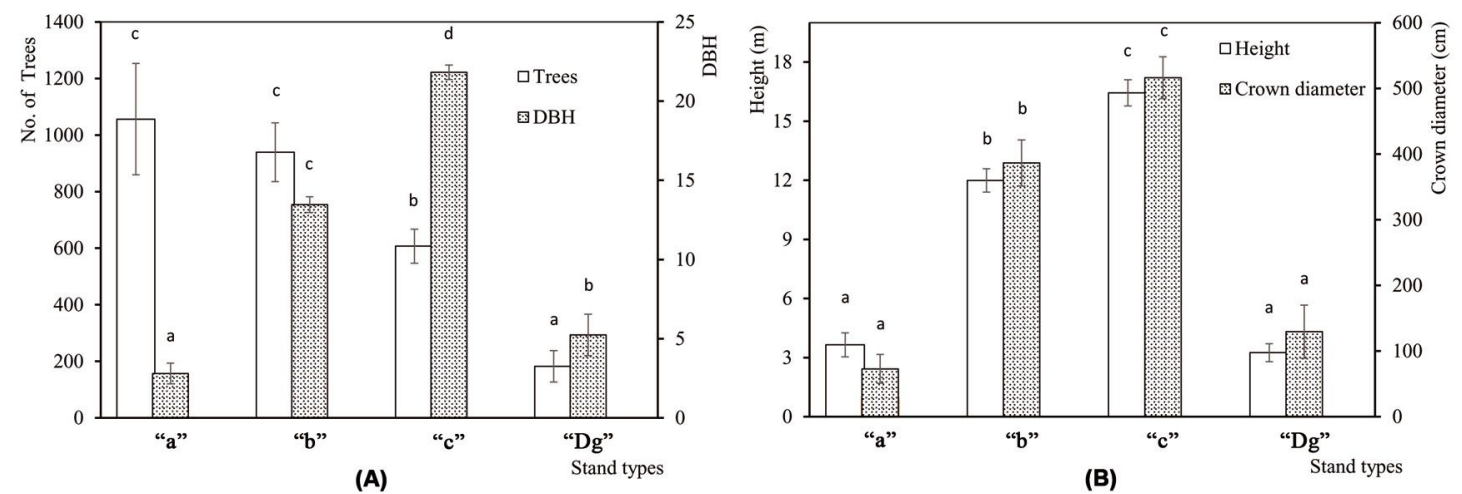

Fig. 3 - Mean structural characteristics of the four stand type classes analyzed. (A) Mean number of trees per hectare (Trees) and diameter at breast height (DBH). (B) Tree height and crown diameter. ("a"): mean DBH 0-8 cm; ("b"): mean DBH 9-20 cm; ("c"): mean DBH 21-36 $\mathrm{cm}$; ("Dg"): degraded stands with a canopy closure $<10 \%$. Error bars represent the standard deviation. Different letters among bars indicate significant differences after ANOVA $(\mathrm{p}<0.05)$. 
Tab. 2 - The number of arthropod Recognizable Taxonomic Units (RTU's) and individuals (in parentheses) collected by the different sampling methods.

\begin{tabular}{lcccc}
\hline Trap type & $\begin{array}{c}\text { Number } \\
\text { of traps }\end{array}$ & $\begin{array}{c}\text { No. of RTUs } \\
\text { (max) }\end{array}$ & $\begin{array}{c}\text { No. of speci- } \\
\text { mens (max) }\end{array}$ & $\begin{array}{c}\text { Means of Speci- } \\
\text { mens } \pm \text { SE }\end{array}$ \\
\hline Pitfall Trap (Pt) & 197 & $46(7)$ & $3783(461)$ & $19.20 \pm 2.79$ \\
Sweepnet (Sw) & 100 & $143(32)$ & $4833(148)$ & $48.33 \pm 3.53$ \\
Sticky Trap (St) & 100 & $98(26)$ & $4062(187)$ & $40.62 \pm 3.25$ \\
Shaking (Sc) & 100 & $48(7)$ & $406(10)$ & $4.06 \pm 0.23$ \\
Total & 497 & 193 & 13084 & $26.33 \pm 2.09$ \\
\hline
\end{tabular}

ber of RTUs $\left(\mathrm{F}_{[3,493]}=73.31, \mathrm{P}<0.001\right)$ and the number of specimens $\left(\mathrm{F}_{[3,493]}=531.8, \mathrm{P}\right.$ $<0.001)$ varied according to trapping methods. Most taxa were captured with sweepnets, and most specimens with sticky traps (Fig. 4a). The ANOVA revealed a significant influence of the sampling site on the number of RTUs $\left(\mathrm{F}_{[4,45]}=10.56, \mathrm{P}<0.001\right)$ and $H^{\prime}$ $\left(\mathrm{F}_{[4,45]}=2.60, \mathrm{P}=0.048\right)$, but not on the number of specimens $\left(\mathrm{F}_{[4,45]}=1.51, \mathrm{P}=\right.$
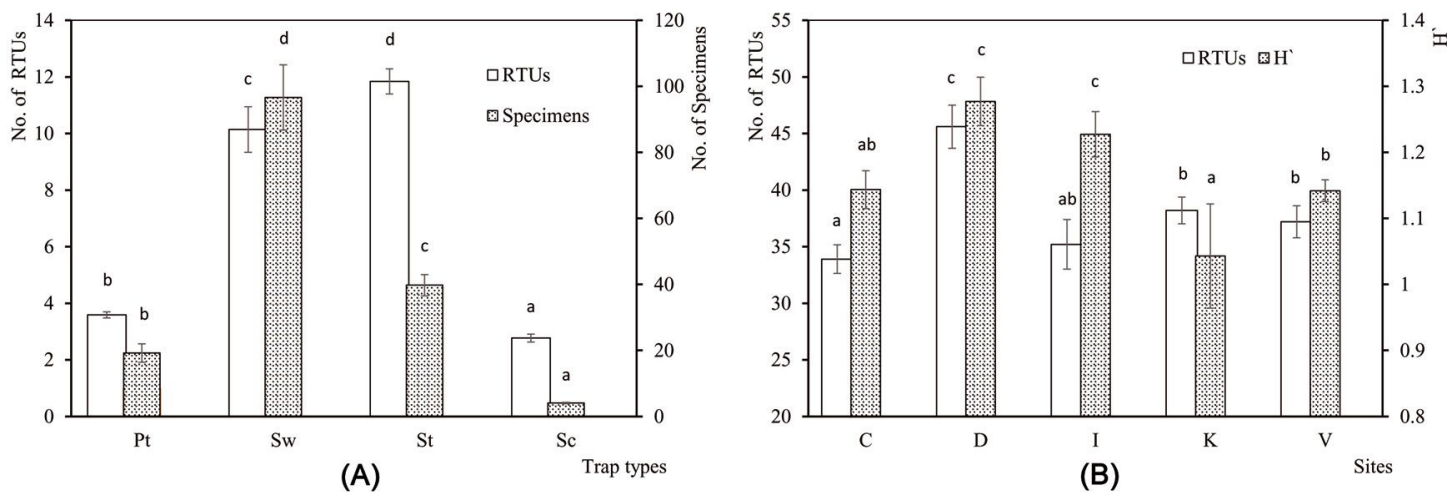

Fig. 4 - Relationships between species characteristics, trap types and sampling sites. (A) Mean number of Recognizable Taxonomic Units (RTUs) and mean number of specimens collected by different trap types (Pt: Pitfall trap, Sw: Sweepnet, St: Sticky trap, Sc: Shaking). (B) Mean number of RTUs and Shannon-Wiener index $\left(H^{\prime}\right)$ across sampling sites (C: Catalca, D: Demirkoy, I: Igneada, K: Kirklareli, V: Vize). Error bars represent the standard deviation. Different letters among bars indicate significant differences after ANOVA ( $p<0.05)$.

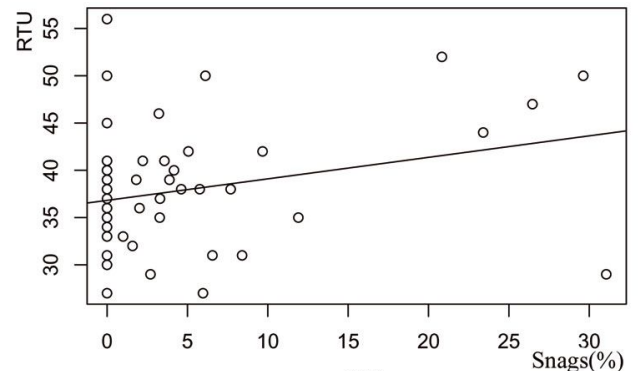

(A)

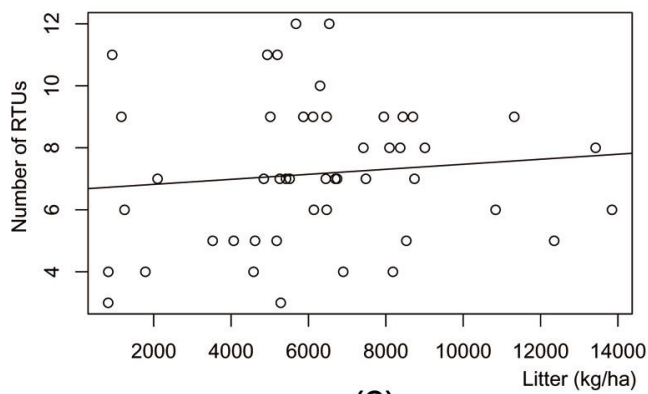

(C)

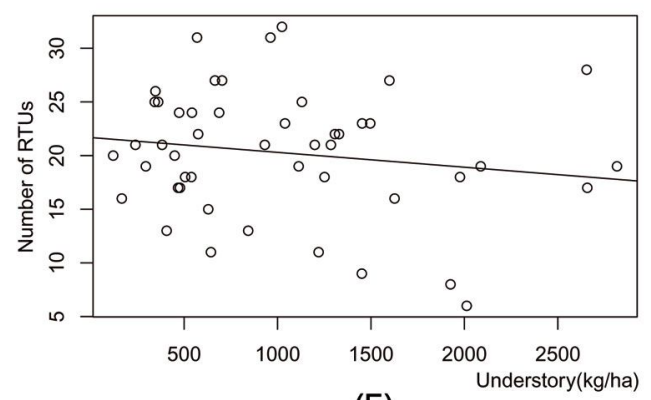

(E)

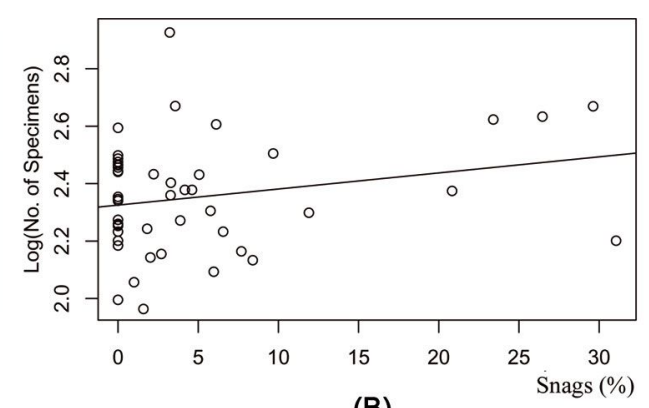

(B)

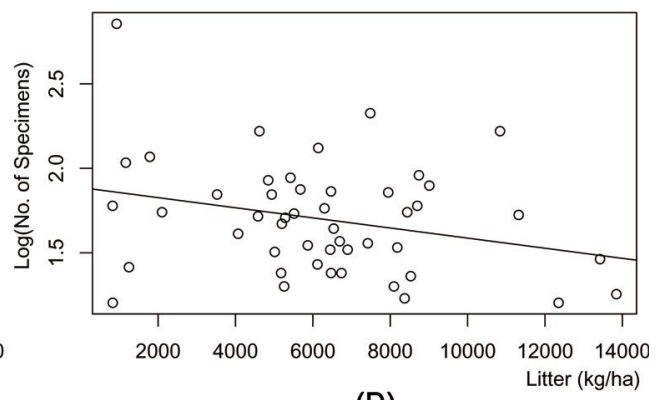

(D)

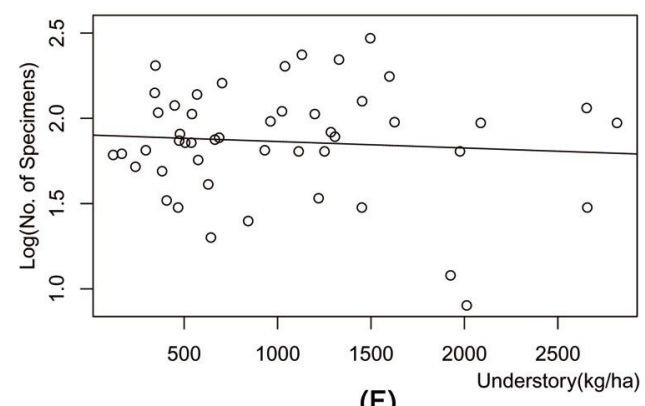

Fig. 5 - Results of the regression analysis between arthropod diversity and stand structural characteristics. (A): Number of Recognizable Taxonomic Units (RTU) vs. percentage of snags; (B): number of specimens (log) vs. percentage of snags; (C): number of RTU (based on pitfall trapping only) vs. litter mass; (D) number of specimens (log) from pitfall trapping only $v s$. litter mass; (E): number of RTU (based on sweepnet sampling only) vs. understory mass; (F); number of specimens (log) from sweepnet sampling only $v s$. understory mass. 
0.214). $H^{\prime}$ was higher in Demirkoy and Igneada and more taxa were counted in Demirkoy (Fig. 4b). Based on the results of multiple regression analyses, elevation $(E)$ and precipitation $(P r)$ significantly affected the number of RTUs $(y=28.65+0.019 E+$ $\left.0.002 \operatorname{Pr}, \mathrm{R}^{2}=0.41, \mathrm{P}<0.001\right)$, the number of specimens $(y=187.62+0.224 E-0.028$ $\left.\operatorname{Pr}, \mathrm{R}^{2}=0.14, \mathrm{P}=0.036\right)$ and $H^{\prime}(y=0.819+$ $0.00014 E+0.00035 P r, \mathrm{R}^{2}=0.18, \mathrm{P}<$ 0.001 ).

In the pitfall samples, the number of RTUs $\left(y=36.82+0.228 x, \mathrm{R}^{2}=0.074, \mathrm{P}<0.001\right)$ and the number of specimens $(y=2.325+$ $\left.0.006 x, \mathrm{R}^{2}=0.055, \mathrm{P}<0.001\right)$ was positively influenced by the percentage of snags (Fig. 5a, Fig. 5b). There was a weak positive relation between the litter layer mass and the number of RTUs $\left(y=6.658+8.10^{-5} x, \mathrm{R}^{2}=\right.$ $0.012, \mathrm{P}<0.001$ ), and a weak negative relation between litter layer mass and the number of specimens $\left(y=1.886-3.10^{-5} x, \mathrm{R}^{2}=\right.$ $0.078, \mathrm{P}<0.001$ - Fig. 5c, Fig. 5d). Also, in the sweep net samples, there was no clear relationship between understory mass and the number of RTUs $\left(y=21.683-0.0014 x, \mathrm{R}^{2}\right.$ $=0.026, \mathrm{P}<0.001$ ), or with understory mass and number of specimens $\left(y=1.902-3 \cdot 10^{-5}\right.$ $x, \mathrm{R}^{2}=0.006, \mathrm{P}<0.001$ - Fig. 5e, Fig. 5f).

Stand types did not significantly differ in their diversity indices $\left(\mathrm{F}_{[3,46]}=0.42, \mathrm{P}=\right.$ $0.743)$, the number of RTUs $\left(F_{[3,46]}=0.446\right.$, $\mathrm{P}=0.722)$ or in the number of specimens $\left(\mathrm{F}_{[3,46]}=0.580, \mathrm{P}=0.631\right)$. The relationship
Tab. 3 - AIC $_{c}$ statistics of the 7 regression models for the prediction of Shannon-Wiener index $\left(H^{\prime}\right)$ of arthropod diversity using diameter at breast height (DBH), height and crown diameter of trees as predictors $(n=50)$. Models are sorted from the lowest to the highest $\triangle \mathrm{AIC}_{\mathrm{c}}$ value. The total number of estimable parameters $(\mathrm{K})$ and Akaike weights $\left(\mathrm{w}_{\mathrm{i}}\right)$ are reported.

\begin{tabular}{ccccccccc}
\hline Model & $\begin{array}{c}\mathbf{D B H} \\
(\mathbf{c m})\end{array}$ & $\begin{array}{c}\text { Height } \\
\mathbf{( m )}\end{array}$ & $\begin{array}{c}\text { Crown } \\
\text { diameter } \\
\mathbf{( m )}\end{array}$ & $\mathbf{K}$ & $\mathbf{A I C}_{\mathbf{c}}$ & $\mathbf{\Delta A I C}$ & $\mathbf{w}_{\mathbf{i}}$ & $\mathbf{R}^{\mathbf{2}}$ \\
\hline 1 & - & $\times$ & - & 2 & -30.090 & 0.000 & 0.3304 & 0.04 \\
2 & $\times$ & - & - & 2 & -29.732 & 0.358 & 0.2763 & 0.03 \\
3 & - & $\times$ & $\times$ & 3 & -27.903 & 2.187 & 0.1107 & 0.07 \\
4 & $\times$ & $\times$ & - & 3 & -27.873 & 2.217 & 0.1090 & 0.04 \\
5 & - & - & $\times$ & 2 & -27.276 & 2.814 & 0.0809 & $<0.01$ \\
6 & $\times$ & - & $\times$ & 3 & -26.650 & 3.440 & 0.0591 & 0.04 \\
7 & $\times$ & $\times$ & $\times$ & 4 & -25.520 & 4.570 & 0.0336 & 0.07 \\
\hline
\end{tabular}
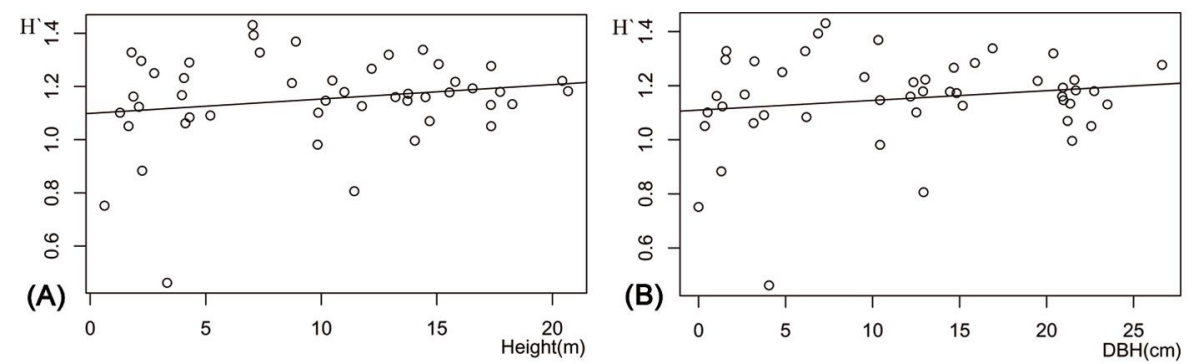

Fig. 6 - Variation of the Shannon-wiener index $\left(H^{\prime}\right)$ with (A) mean tree height and (B) mean diameter at breast height (DBH) of the sampled stands.

between DBH and RTU richness was weak, number of specimens was weakly negative but positive $\left(y=37.75+0.016 x, \mathrm{R}^{2}=0.003, \quad\left(y=263.23-1.16 x, \mathrm{R}^{2}=0.005, \mathrm{P}<0.001\right)\right.$. $\mathrm{P}<0.001$, while that between DBH and the The best predictive models for the Shannon-

Tab. 4 - Number and percentage of specimens (with abundance $>1 \%$ ) classified in each Recognizable Taxonomic Units (RTU) using the four sampling methods described (pitfall traps, sweepnet, sticky traps, shaking), and their average ( \pm standard error) across the four stand type classes considered. (“a”): mean DBH 0-8 cm; ("b"): mean DBH 9-20 cm; ("c"): mean DBH 21-36 cm; ("Dg"): degraded stands with a canopy closure $<10 \%$. All taxa varied significantly among trap types $(\mathrm{P}<0.01)$. $(\mathrm{R})$ : Correlation coefficient with the average diameter at breast height $(\mathrm{DBH})$ of plots and the number of specimens. (P): p-value after ANOVA between stand types and the number of specimens. $(*): \mathrm{p}<0.1 ;(* *): \mathrm{p}<0.05)$.

\begin{tabular}{|c|c|c|c|c|c|c|c|c|c|c|c|c|}
\hline \multirow[b]{2}{*}{ RTU } & \multirow[b]{2}{*}{$\underbrace{e}_{\substack{j \\
0}}$} & \multirow[b]{2}{*}{ 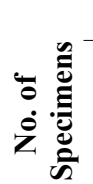 } & \multicolumn{4}{|c|}{ Sampling Method } & \multicolumn{4}{|c|}{ Stand type } & \multirow[b]{2}{*}{$\mathbf{R}$} & \multirow[b]{2}{*}{$\mathbf{P}$} \\
\hline & & & 恶总 & 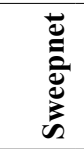 & 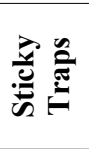 & 犎 & “a” & "b" & “c" & "Dg" & & \\
\hline Araneae & 13 & 1691 & 414 & 1070 & 78 & 129 & $29.5 \pm 4.1$ & $33.3 \pm 5.0$ & $37.5 \pm 3.9$ & $37.2 \pm 5.4$ & 0.17 & 0.475 \\
\hline Insecta & 1 & 146 & 0 & 4 & 140 & 2 & $5.2 \pm 2.7$ & $2.5 \pm 0.9$ & $1.5 \pm 0.7$ & $1.6 \pm 0.4$ & -0.13 & 0.830 \\
\hline Lepidoptera & 1 & 136 & 0 & 119 & 12 & 5 & $2.3 \pm 0.6$ & $3.2 \pm 0.7$ & $3.0 \pm 0.5$ & $1.6 \pm 0.4$ & 0.15 & 0.509 \\
\hline Chalcidoidea & 6 & 766 & 5 & 142 & 614 & 5 & $15.2 \pm 2.3$ & $15.7 \pm 4.6$ & $14.6 \pm 2.7$ & $16.8 \pm 3.1$ & -0.04 & 0.985 \\
\hline Chrysomelidae & 1 & 133 & 0 & 71 & 52 & 10 & $4.0 \pm 1.3$ & $1.9 \pm 0.7$ & $1.8 \pm 0.6$ & $3.4 \pm 1.6$ & -0.25 & 0.459 \\
\hline Entomobryidae & 2 & 249 & 249 & 0 & 0 & 0 & $4.4 \pm 1.1$ & $5.5 \pm 1.3$ & $5.8 \pm 2.0$ & $2.8 \pm 1.2$ & 0.20 & 0.686 \\
\hline Dolichopodidae & 2 & 233 & 6 & 140 & 86 & 1 & $5.5 \pm 2.5$ & $3.2 \pm 0.7$ & $3.3 \pm 0.7$ & $10.6 \pm 4.2$ & -0.15 & $0.072 *$ \\
\hline Luaxanidae & 1 & 142 & 0 & 21 & 120 & 1 & $3.5 \pm 0.5$ & $2.8 \pm 0.6$ & $2.5 \pm 0.6$ & $1.8 \pm 0.7$ & -0.08 & 0.517 \\
\hline Lygaeidae & 2 & 272 & 2 & 267 & 0 & 3 & $17.0 \pm 15.4$ & $0.1 \pm 0.1$ & $0.5 \pm 0.3$ & $1.8 \pm 1.3$ & -0.34 & $0.075^{*}$ \\
\hline Aphidae & 2 & 227 & 0 & 164 & 56 & 7 & $3.7 \pm 0.8$ & $3.9 \pm 1.1$ & $6.6 \pm 3.8$ & $2.6 \pm 1.7$ & 0.17 & 0.639 \\
\hline Cercopidae & 3 & 411 & 2 & 282 & 123 & 4 & $4.7 \pm 1.5$ & $8.4 \pm 3.2$ & $13.5 \pm 5.6$ & $2.4 \pm 1.9$ & 0.22 & 0.296 \\
\hline Cicadellidae & 7 & 864 & 3 & 347 & 509 & 5 & $8.0 \pm 1.4$ & $18.3 \pm 3.2$ & $27.8 \pm 7.0$ & $10.4 \pm 2.8$ & 0.42 & $0.027^{* *}$ \\
\hline Braconidae & 3 & 446 & 0 & 54 & 392 & 0 & $9.4 \pm 4.6$ & $6.7 \pm 2.3$ & $12.7 \pm 6.5$ & $2.8 \pm 1.1$ & 0.10 & 0.640 \\
\hline Formicidae & 23 & 2945 & 2673 & 166 & 15 & 91 & $57.6 \pm 15.1$ & $44.7 \pm 13.1$ & $36.7 \pm 10.1$ & $172.0 \pm 130.1$ & -0.22 & $0.056^{*}$ \\
\hline Ichneumonidae & 1 & 132 & 0 & 85 & 46 & 1 & $1.4 \pm 0.3$ & $3.1 \pm 0.6$ & $3.9 \pm 0.7$ & $1.0 \pm 0.8$ & 0.42 & $0.004^{* *}$ \\
\hline Tettigoniidae & 2 & 213 & 3 & 189 & 0 & 21 & $4.0 \pm 1.0$ & $4.6 \pm 1.4$ & $4.7 \pm 1.4$ & $2.8 \pm 1.1$ & 0.11 & 0.723 \\
\hline Thripidae & 7 & 856 & 0 & 14 & 842 & 0 & $39.2 \pm 14.6$ & $9.9 \pm 3.0$ & $5.7 \pm 1.0$ & $7.0 \pm 2.7$ & -0.38 & $0.076^{*}$ \\
\hline Others & 25 & 3222 & 426 & 1698 & 977 & 121 & - & - & - & - & - & - \\
\hline Total & 100 & 13084 & 3783 & 4833 & 4062 & 406 & - & - & - & - & - & - \\
\hline
\end{tabular}




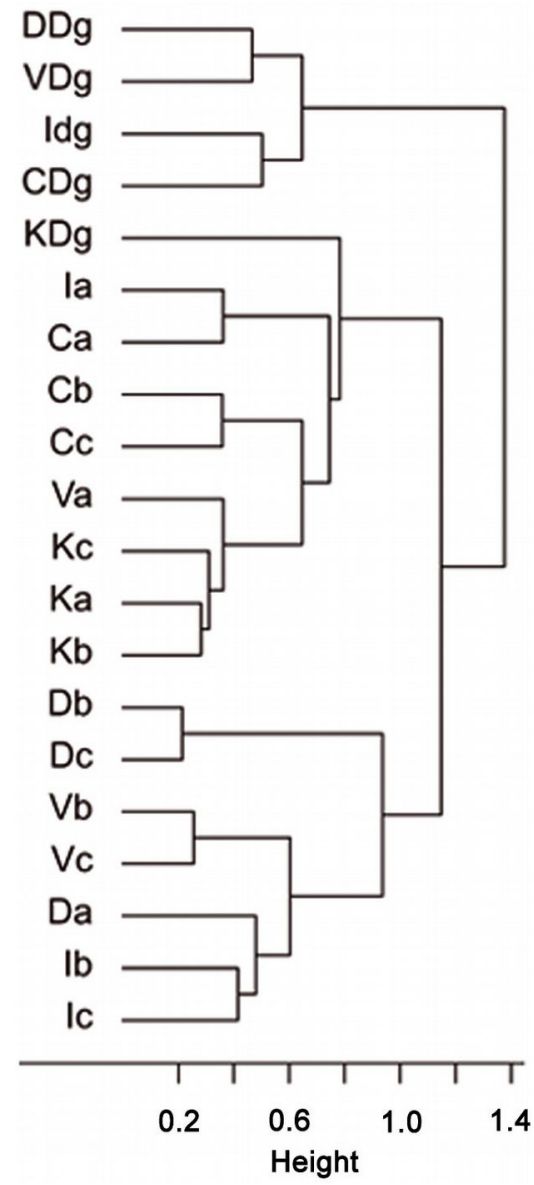

Fig. 7 - Cluster analysis of stand types based on the similarity of Recognizable Taxonomic Units (RTU) using Ward's linkage and Bray-Curtis distance metrics. The first letter of labels refers to sampling sites $(\mathrm{C}$ : Catalca; D: Demirkoy; I: Igneada; K: Kirklareli; V: Vize), the second letter refers to stand types ("a": mean DBH 0-8 cm; "b": mean DBH 9-20 cm; "c": mean DBH 21-36 cm; "Dg": degraded stands with a canopy closure $<10 \%$ )

Fig. 9 - Results of the PC analysis of stand types ("a": mean DBH 0-8 cm; "b": 9-20 cm; "c": 21-36 cm; "Dg": degraded stands with canopy closure $<10 \%$ ) based on the following variables: total number of RTU and total number of specimens across all trap types, number of RTUs and number of specimens within each trap type (pitfall trap, sweepnet, sticky trap and cloth shaking),

$H^{\prime}$, elevation, number of trees, $\mathrm{DBH}$, height, crown diameter, number of snags, litter mass and understory mass.
Wiener index was determined based on the smallest $\mathrm{AIC}_{\mathrm{c}}$ values. For $\mathrm{AIC}_{\mathrm{c}}<2$, these were $H^{\prime}=1.0987+0.0054$. height and $H^{\prime}=$ $1.1096+0.001 \cdot \mathrm{DBH}$ (Tab. 3). The relation between arthropod $H^{\prime}$ and tree DBH and height was weak (Fig. 6a, Fig. 6b). Also, the composite model for Shannon-Wiener index was $H^{\prime}=1.10793+0.0018 \cdot \mathrm{DBH}+0.0051$ -height - 0.0067 crown diameter. In the model, tree height $\left(t_{49}=22.92, \mathrm{P}<0.001\right)$, DBH $\left(t_{49}=25.06, \mathrm{P}<0.001\right)$ and the composite model $\left(t_{49}=19.46, \mathrm{P}<0.001\right)$ were significant for $H^{\prime}$.

Overall, seventeen taxa within RTUs were found to comprise more than $1 \%$ of the captured arthropods, corresponding to $75 \%$ of the total specimens. Each of the 17 taxa varied significantly based on trap type $(\mathrm{P}<$ 0.01 - Tab. 4). There was a mid-level positive relation between DBHs and number of specimens of Cicadellidae and Ichneumonidae $(\mathrm{R}=0.42)$, and a mid-level negative relation between DBHs and number of specimens of Lygaeidae $(\mathrm{R}=-0.32)$ and Thripidae $(\mathrm{R}=-0.38)$. Significant differences among stand types were found for Dolichopodidae $\left(\mathrm{F}_{[3,46]}=2.495, \mathrm{P}=0.072\right)$, Lygaeidae $\left(\mathrm{F}_{[3,46]}=2.459, \mathrm{P}=0.075\right)$, Cicadellidae $\left(\mathrm{F}_{[3,46]}=3.358, \mathrm{P}=0.027\right)$, Formicidae $\left(\mathrm{F}_{[3,46]}=2.713, \mathrm{P}=0.056\right)$, Ichneumonidae $\left(\mathrm{F}_{[3,46]}=5.051, \mathrm{P}=0.004\right)$ and Thripidae $\left(\mathrm{F}_{[3,46]}=2.452, \mathrm{P}=0.076\right.$ - Tab. 4).

Cluster analysis of stand types based on RTUs formed three large clusters, showing that both sampling sites and stand types were significantly dissimilar $(\mathrm{R}=0.15, \mathrm{P}=0.038$ and $\mathrm{R}=0.255, \mathrm{P}=0.001$, respectively - Fig. $7)$, as well as trap types ( $\mathrm{R}=0.823, \mathrm{P}$ $<0.001$ - Fig. 8). Results of the PCA based on 19 parameters (total number of RTU and total number of specimens across all trap types; number of RTUs and number of specimens within each trap type: pitfall trap, sweepnet, sticky trap and cloth shaking; $H^{\prime}$; elevation; number of trees per ha; $\mathrm{DBH}$;

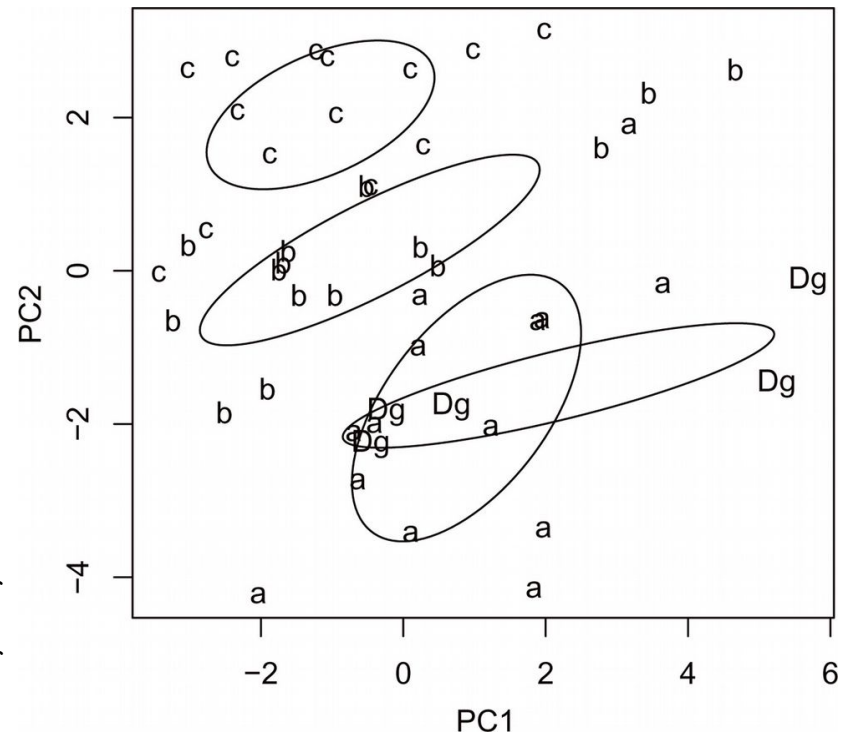

height; crown diameter; percentage of snags; litter mass; understory mass) showed a fairly good discrimination of stand types along the first two axes (Fig. 9), with significant differences among stand type classes $\left(\mathrm{F}_{[3,44]}=\right.$ $4.43, \mathrm{P}<0.001)$. The first principal compo-

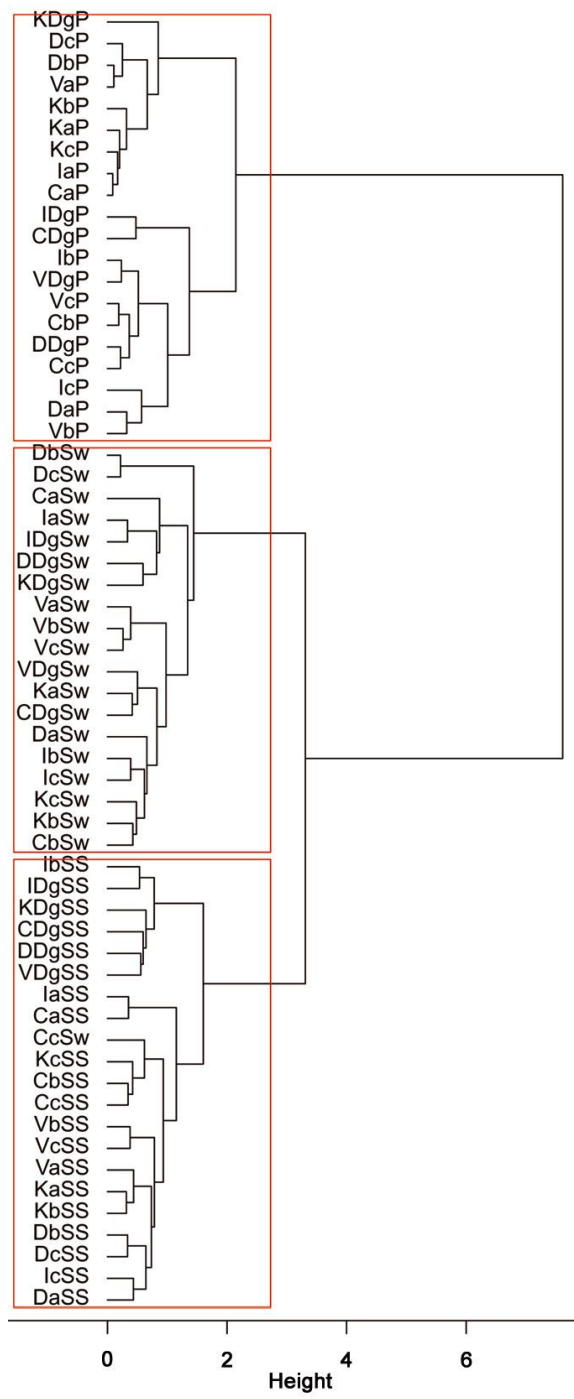

Fig. 8 - Cluster analysis of different sampling methods adopted at the different stand types and sampling sites, based on the similarityy of Recognizable Taxonomic Units (RTU) using Ward's linkage and Bray-Curtis distance metrics. The dendrogram indicate a greater separation between soildwelling arthropod composition and canopy or sub-canopy arthropod composition than between canopy and sub-canopy arthropod communities. The first letter of labels refers to sampling sites (C: Catalca; D: Demirkoy; I: Igneada; K: Kirklareli; V: Vize), the second letter refers to stand types ("a": mean DBH 0-8 cm; "b": mean DBH 9-20 cm; "c": mean DBH 21-36 cm; "Dg": degraded stands with a canopy closure $<10 \%$ ), while the last letter(s) refers to the sampling method (P: Pitfall trap; Sw: Sweepnet; SS: Sticky trap and Shaking). 
nent (PC1) accounted for approximately $27 \%$ of the total variation, and showed a high correlation with total number of RTUs $(\mathrm{r}=0.73)$, RTUs richness in sticky trap sampling $(\mathrm{r}=0.73)$, and elevation $(\mathrm{r}=0.69)$ PC2 explained $21 \%$ of the total variation, and showed the highest correlations with DBH $(r=0.79)$, tree height $(r=0.72)$ and RTU in sweep net sampling $(r=0.71$ - Fig. 9).

\section{Discussion}

Arthropod richness, diversity and composition were influenced by climate and elevation in Thrace. Indeed, species richness, number of specimens and biodiversity increased with elevation and precipitation. The observed increase in diversity with elevation may be due, in part, to the local covariation of such factors, as reported for many temperate and arid habitats (Sanders et al. 2003). Abundance of most arthropod taxa increased with elevation (Uetz et al. 1979). Some insect species increased their frequency with elevation up to $600-800 \mathrm{~m}$, and then decreased in southwestern USA (McCoy 1990). In tropical forest, insect species richness, number of individuals and diversity increased up to $1000 \mathrm{~m}$, and then declined (Wolda 1987).

Our results did not confirm that arthropod richness and biodiversity were specifically affected by stand types in young and middleaged forests, but arthropod diversity, richness and the number of specimens did increase slightly with DBH. In oak forest, herbivore species richness and density correlated positively with forest age (Jeffries et al. 2006). In this study, DBH, height and crown diameter did impact on biodiversity, although crown diameter had the least influence.

Some arthropods are often used as bioindicators (King et al. 1998, Langor \& Spence 2006, Maleque et al. 2009). For example, Formicidae have been used as bioindicators of ecological degradation, concomitant with decreasing litter and canopy (King et al 1998), such as in our study. Using more than one taxon as an indicator of environmental conditions or biodiversity can be problematic, since a taxonomic group may behave differently from other groups (Finch 2005). However, several authors recommended the use of multiple taxonomic indicators as each species group is related with different habitat characteristics (Jonsson \& Jonsell 1999). Our results showed that the density of Formicidae, Thripidae, Lygaeidae, Dolichopodidae and Luaxanidae declined, while the density of Cicadellidae and Ichneumonidae increased with forest age. Dolek et al. (2009) also found that Formicidae species decreased from pasture coppice oak to high forest in Germany. Although Araneae are often used as indicators (Platen 2003, Coote et al. 2013), we found their abundance only slight- ly increasing with age. Analogously, Barsoum et al. (2014) found that Araneae and Carabidae diversity showed no differences between monoculture pine and monoculture oak stands, as well as Spitzer et al. (2008), who investigated the effects of stand openness on carabids, arachnids and myriapodsisopods in lowland deciduous woodland. In a boreal forest context, Niemela et al. (1996) found that populations of Araneae, Formicidae and Carabidae showed an increasing trend only after the first 20 years. Collembola have been reported as more abundant in coppices than in other forest types (LaugaReyrel \& Deconchat 1999); however, their abundance was not clearly delineated among coppice oak stand types in our study.

Although Sessile oak, Hungarian oak, Turkey oak, Pedunculate oak and Aleppo oak are fairly common oak species in Thrace (Yaltirik \& Efe 1988, Makineci 2005), the latter two species were absent at our study sites. This could be due to the overall rarity of Aleppo oak on one side, and on the other side to the absence in the studied areas of floodplain forests, which have a high abundance of Pedunculate oak (Kavgaci et al. 2010). Forest structure, tree species, climate, elevation and parent material influence understory and density of oak species (Yarci 2000). Litter increased with understory and stand age (Makineci et al. 2011). Relationships between the arthropod community and understory in our study were inconclusive. Although the relationship between coarse woody debris and arthropod communities varies (Hanula et al. 2006, Ulyshen \& Hanula 2009), it is known that both woody debris and deadwood abundance can increase arthropod diversity (Topp et al. 2006). Coarse woody debris not only increases arthropod species numbers, but also functional diversity (Jabin et al. 2004). The removal and addition of litter had no influence on arthropod diversity and taxonomic richness in lowland rainforests (Ashford et al. 2013). In general, arthropod diversity increases with vegetation height, complexity (Longcore 2003) and plant species richness (Knops et al. 1999, Symstad et al. 2000).

Cluster analysis suggested that the RTUs composition of degraded forests differed from other stand types, except at Kirklareli, but young and middle-aged forests were not clearly separated by differences in arthropod taxonomy. In cluster analysis, trap types were separated from each other, except for the sweep net trap in the "c" stand type in Catalca (CcSw). Arthropod taxonomic composition was similar between canopy (sticky traps and cloth shaking) and sub-canopy (sweepnet) locations, because of their similar ecology, whereas composition of soil-dwelling arthropods (pitfalls) differed more than canopy and sub-canopy communities. A separation between stand types was demon- strated by PCA based on 19 different parameters, with degraded forest and young forests exhibiting similar characteristics. Effects of site history on insect communities may continue for more than 20 years postharvest (Goßner et al. 2008).

\section{Conclusion}

The results of the present study show that arthropod richness, diversity and composition in Thrace were not significantly distinguished in young and middle-aged forest stand types in coppice oak forests, although biodiversity, richness and number of specimens did slightly increase with DBH and tree height. As the coppice oak changes to mature forest, similar studies are needed to better assess the relation between arthropods and forest type and characteristics.

Several insect families could potentially be used as indicators for coppice oak conditions due to their decreasing (Formicidae, Thripidae, Lygaeidae, Dolichopodidae and Luaxanidae) or increasing (Cicadellidae and Ichneumonidae) abundance with forest age. However, in our study Araneae, which are often used as indicators, were not useful to this purpose. Arthropod taxonomic composition of degraded forests was clearly separated from the other stand types.

\section{Acknowledgements}

This study is part of the project "Determination of Health Condition, Biomass, Carbon Sequestration and Faunistic Characteristics on Conversion of Coppice Oak Ecosystems in Northern Thrace", supported by the Scientific and Technological Research Council of Turkey (TUBITAK), Project no. TOVAG-107O750 (Coordinator: E. Makineci).

The Istanbul Regional Forestry Directorate for their assistance and support in the field is acknowledged. We thank Dr. George M. Merovich (Division of Forestry and Natural Resources, West Virginia University, USA) for advice on statistical analyses.

\section{References}

Akbulut S, Keten A, Stamps WT (2003). Effect of alley cropping on crops and arthropod diversity in Duzce, Turkey. Journal of Agronomy and Crop Science 189 (4): 261-269. - doi: 10.1046/ j.1439-037X.2003.00042.x

Ashford O, Foster W, Turner B, Sayer E, Sutcliffe L, Tanner E (2013). Litter manipulation and the soil arthropod community in a lowland tropical rainforest. Soil Biology and Biochemistry 62: 512. - doi: 10.1016/j.soilbio.2013.03.001

Barsoum N, Fuller L, Ashwood F, Reed K, Bonnet-Lebrun AS, Leung F (2014). Ground-dwelling spider (Araneae) and carabid beetle (Coleoptera: Carabidae) community assemblages in mixed and monoculture stands of oak (Quercus robur L./Quercus petraea (Matt.) Liebl.) and Scots pine (Pinus sylvestris L.). Forest Ecology 
and Management 321: 29-41. - doi: 10.1016/j.foreco.2013.08.063

Bolger DT, Suarez AV, Crooks KR, Morrison SA, Case TJ (2000). Arthropods in urban habitat fragments in southern California: area, age and edge effects. Ecological Applications 10 (4) 1230-1248. - doi: 10.1890/1051-0761(2000)010 [1230:AIUHFI]2.0.CO;2

Burnham KP, Anderson DR (2002). Model selection and inference: a practical information - theoretic approach $\left(2^{\text {nd }}\right.$ edn). Springer Science \& Business Media, New York, USA, pp. 488. [online] URL: http://books.google.com/books?\&id= fT1 Iu-h6E-oC

Coote L, Dietzsch AC, Wilson MW, Graham CT, Fuller L, Walsh AT, Irwin S, Kelly DL, Mitchell FJ, Kelly TC, O'Halloran J (2013). Testing indicators of biodiversity for plantation forests. Ecological Indicators 32: 107-115. - doi: 10.1016/j. ecolind.2013.03.020

Dolek M, Freese-Hager A, Bussler H, Floren A, Liegl A, Schmidl J (2009). Ants on oaks: effects of forest structure on species composition. Journal of Insect Conservation 13 (4): 367-375. - doi 10.1007/s10841-008-9181-2

Engelmann MD (1961). The role of soil arthropods in the energetics of an old field community. Ecological Monographs 31 (3): 221. - doi: 10.23 07/1948553

Finch OD (2005). Evaluation of mature conifer plantations as secondary habitat for epigeic forest arthropods (Coleoptera: Carabidae; Araneae). Forest Ecology and Management 204 (1) 23-36. - doi: 10.1016/j.foreco.2004.07.071

Goßner M, Engel K, Jessel B (2008). Plant and arthropod communities in young oak stands: are they determined by site history? Biodiversity and Conservation 17 (13): 3165-3180. - doi: 10.100 7/s10531-008-9418-0

Hamilton J, Zangerl AR, Berenbaum MR, Sparks JP, Elich L, Eisenstein A, Delucia EH (2012). Elevated atmospheric $\mathrm{CO}_{2}$ alters the arthropod community in a forest understory. Acta Oecologica 43: 80-85. - doi: 10.1016/j.actao.2012.05.00 4

Hanula JL, Horn S, Wade DD (2006). The role of dead wood in maintaining arthropod diversity on the forest floor. Gen Tech Rep SRS-93, USDA Forest Service, Southern Research Station, Asheville, NC, USA, pp 57-66. [online] URL: http:// www.srs.fs.fed.us/pubs/24878

Jabin M, Mohr D, Kappes H, Topp W (2004). Influence of deadwood on density of soil macroarthropods in a managed oak-beech forest. Forest Ecology and Management 194 (1-3): 61-69. doi: 10.1016/j.foreco.2004.01.053

Jeffries JM, Marquis RJ, Forkner RE (2006). Forest age influences oak insect herbivore community structure, richness, and density. Ecological Applications 16 (3): 901-912. - doi: 10.1890/10 51-0761(2006)016[0901:FAIOIH]2.0.CO;2

Jonsson BG, Jonsell M (1999). Exploring potential biodiversity indicators in boreal forests. Biodiversity and Conservation 8 (10): 1417-1433. doi: 10.1023/A:1008900309571

Kavgaci A, Carni A, Tecimeni B, Özalp G (2010).
Diversity and ecological differentiation of oak forests in NW Thrace (Turkey). Archives of Biological Sciences 62 (3): 705-718. - doi: 10.2298/ ABS1003705K

King JR, Andersen AN, Cutter AD (1998). Ants as bioindicators of habitat disturbance: validation of the functional group model for Australia's humid tropics. Biodiversity and Conservation 7 (12): 1627-1638. - doi: 10.1023/A:10088 57214743

Knops J, Tilman D, Haddad N, Naeem S, Mitchell C, Haarstad J, Ritchie M, Howe K, Reich P, Siemann E, Groth J (1999). Effects of plant species richness on invasion dynamics, disease outbreaks, insect abundances and diversity. Ecology Letters 2 (5): 286-293. - doi: 10.1046/j.1461-02 48.1999.00083.x

Langor DW, Spence JR (2006). Arthropods as ecological indicators of sustainability in Canadian forests. The Forestry Chronicle 82 (3): 344350. - doi: $10.5558 / \mathrm{tfc} 82344-3$

Lauga-Reyrel F, Deconchat M (1999). Diversity within the Collembola community in fragmented coppice forests in south-western France. European Journal of Soil Biology 35 (4): 177-187. doi: 10.1016/S1164-5563(10)70004-2

Leatherberry EC, Moser WK, Perry C, Woodall C, Jespen E, Pennington S, Flickinger A (2006). Iowa's forests 1999-2003 (Part A). Resource Bull NC-266A, USDA Forest Service, North Central Research Station, St. Paul, MN, USA, pp. 84. [online] URL: http://www.treesearch.fs. fed.us/pubs/19028

Longcore T (2003). Terrestrial arthropods as indicators of ecological restoration success in coastal sage scrub (California, USA). Restoration Ecology 11 (4): 397-409. - doi: 10.1046/j.1526-100X. 2003.rec0221.x

Makineci E (2005). Trakya'da mese ormanlarinin tür zenginligi, koruya dönüstürülmesi ve önemi. [Species richness, converted to high forest, and importance of oak forests in Thrace]. In: Proceedings of the "IV Industrialization and Enviromental Symposium in Thrace". Edirne (Turkey) 14-15 Oct 2005. Bildiriler Kitabi, Edirne, Turkey, pp. 381-389. [in Turkish]

Makineci E, Yilmaz E, Özdemir E, Kumbasli M, Sevgi O, Keten A, Beskardes V, Zengin H, Yilmaz H, Çaliskan S (2011). Kuzey Trakya koruya tahvil mese ekosistemlerinde saglik durumu, biyokütle, karbon depolama ve faunistik özelliklerin belirlenmesi [Determination of health condition, biomass, carbon sequestration and faunistic characteristics on conversion of coppice oak ecosystems in Northern Thrace]. TÜBITAK Project, TUBITAK-TOVAG 1070750, Turkey. [in Turkish]

Maleque MA, Maeto K, Ishii HT (2009). Arthropods as bioindicators of sustainable forest management, with a focus on plantation forests. Applied Entomology and Zoology 44 (1): 1-11. doi: 10.1303/aez.2009.1

McCoy ED (1990). The distribution of insects along elevational gradients. Oikos 58: 313-322. doi: $10.2307 / 3545222$

Niemela J, Haila Y, Puntilla P (1996). The impor- tance of small-scale heterogeneity in boreal forests: variation in diversity in forest-floor invertebrates across the succession gradient. Ecography 19 (3): 352-368. - doi: 10.1111/j.1600-0587. 1996.tb01264.x

Oliver I, Beattie AJ (1993). A possible method for the rapid assessment of biodiversity. Conservation Biology 7 (3): 562-568. - doi: 10.1046/j.152 3-1739.1993.07030562.x

Platen R (2003). Spider assemblages (Arachnida: Araneae) as indicators for degraded oligotrophic moors in north-east Germany. In: Proceedings of the " $21^{\text {st }}$ European Colloquium of Arachnology. European Arachnology 2003" (Logunov DV, Penny D eds). St. Petersburg (Russia) 4-9 August 2003. Arthropoda Selecta Special Issue 1: 249-260.

R Development Core Team (2013). R: a language and environment for statistical computing. $\mathrm{R}$ Foundation for Statistical Computing Vienna, Austria. [online] URL: http://www.r-project.org/ Rainio J, Niemelä J (2003). Ground beetles (Coleoptera: Carabidae) as bioindicators. Biodiversity and Conservation 12 (3): 487-506. - doi: 10.1023/A:1022412617568

Sanders NJ, Moss J, Wagner D (2003). Patterns of ant species richness along elevational gradients in an arid ecosystem. Global Ecology and Biogeography 12 (2): 93-102. - doi: 10.1046/j.1466822X.2003.00324.x

Siemann E, Haarstad J, Tilman D (1999). Dynamics of plant and arthropod diversity during old field succession. Ecography 22 (4): 406-414. doi: 10.1111/j.1600-0587.1999.tb00577.x

Siemann E, Tilman D, Haarstad J, Ritchie M (1998). Experimental tests of the dependence of arthropod diversity on plant diversity. The American Naturalist 152 (5): 738-750. [online] URL: http://www.jstor.org/stable/10.1086/286204

Spitzer L, Konvicka M, Benes J, Tropek R, Tuf IH, Tufova J (2008). Does closure of traditionally managed open woodlands threaten epigeic invertebrates? Effects of coppicing and high deer densities. Biological Conservation 141 (3): 827 837. - doi: 10.1016/j.biocon.2008.01.005

Stamps WT, Linit MJ (1998). Plant diversity and arthropod communities: implications for temperate agroforestry. Agroforestry Systems 39 (1): 73-89. - doi: 10.1023/A:1005972025089

Symstad AJ, Siemann E, Haarstad J (2000). An experimental test of the effect of plant functional group diversity on arthropod diversity. Oikos 89 (2): 243-253. - doi: 10.1034/j.1600-0706.2000. 890204.x

Topp W, Kappes H, Kulfan J, Zach P (2006). Distribution pattern of woodlice (Isopoda) and millipedes (Diplopoda) in four primeval forests of the Western Carpathians (Central Slovakia). Soil Biology and Biochemistry 38 (1): 43-50. - doi: 10.1016/j.soilbio.2005.04.012

Tscharntke T, Gathmann A, Steffan-Dewenter I (1998). Bioindication using trap-nesting bees and wasps and their natural enemies: community structure and interactions. Journal of Applied Ecology 35 (5): 708-719. - doi: 10.1046/j.13652664.1998.355343.x 
Uetz GW, Laan KL, Summers GF, Gibson PA, Getz LL (1979). The effects of flooding on floodplain arthropod distribution, abundance and community structure. American Midland Naturalist 101 (2): 286. - doi: 10.2307/2424594

Ulyshen MD, Hanula JL (2009). Responses of arthropods to large-scale manipulations of dead wood in loblolly pine stands of the southeastern United States. Environmental Entomology 38 (4): 1005-1012. - doi: 10.1603/022.038.0407 Van Straalen NM (1998). Evaluation of bioindicator systems derived from soil arthropod commu- nities. Applied Soil Ecology 9 (1-3): 429-437. doi: 10.1016/S0929-1393(98)00101-2

Wolda H (1987). Altitude, habitat and tropical insect diversity. Biological Journal of the Linnean Society 30 (4): 313-323. - doi: 10.1111/j.10958312.1987.tb00305.x

Work TT, Buddle CM, Korinus LM, Spence JR (2002). Pitfall trap size and capture of three taxa of litter-dwelling arthropods: implications for biodiversity studies. Environmental Entomology 31 (3): 438-448. - doi: 10.1603/0046-225X-31. 3.438
Yaltirik F, Efe A (1988). Trakya vejetasyonuna genel bakis ve Igneada Subasar (Longos) Ormanlari [Thrace vegetation overview and Igneada Longos Forests]. Journal of the Faculty of Forestry of the Istanbul University / I.U. Orman Fakültesi Dergisi Seri B 38 (1): 69-75. [in Turkish]

Yarci C (2000). Demirköy (Istranca Daglari/ Trakya Bölgesi) ve civarinin orman vejetasyonu [Forest vegetation of Demirköy (Strandja Mountain / Thrace Region) and environs]. Ekoloji ve Çevre Dergisi 35: 13-18. [in Turkish] 